\title{
DEVELOPMENT OF INDONESIAN LANGUAGE SKILLS INSTRUCTIONAL MATERIALS BASED PROJECT BASED LEARNING WITH INQUIRY APPROACH
}

\author{
Arum Ratnaningsih, Titi Anjarini \\ Universitas Muhammadiyah Purworejo \\ arumratna@umpwr.ac.id
}

\section{Article History}

accepted 09/07/2018

approved 01/08/2018

published 17/09/2018

\section{Keywords}

bahan ajar, $P B L$, pendekatan Inquiry

\begin{abstract}
The background of this study is the lack of confidence in the use of Indonesian language so that passive students in lecturing activities. The purpose of this study is for humanist learning, active, and fun. Research method of $R \& D$ with learning model of Project Based Learning (PBL) and Inquiry approach. Subjects in this study were PGSD students of University of Muhammadiyah Purworejo totaling 130 students divided into 2 classes as experimental class, 2 classes as control class, and 1 class of scale test. Data analysis used in this research is source triangulation, triangulation method, instrument triangulation, and SPSS. The result of this research is the improvement of Indonesian language skills of PGSD students. The experimental class has a higher score than the control class, so it can be concluded that the PBL learning model can significantly improve the PGSD students' skill in Bahasa Indonesia University of Muhammadiyah Purworejo.
\end{abstract}

Social, Humanities, and Education Studies (SHEs): Conference Series 


\section{PENDAHULUAN}

Bahan ajar dalam proses pembelajaran menjadi kebutuhan yang utama sebagai sumber belajar terdekat. Hal ini sesuai dengan pernyataan dari Tomlinson (2012) bahwa bahan ajar merupakan segala sesuatu yang digunakan oleh pendidik atau mahasiswa untuk memudahkan belajar bahasa, pengetahuan, dan pengalaman berbahasa. Pernyataan tersebut maknanya bahwa bahan ajar mempunyai peran utama dalam proses pembelajaran. Peran bahan ajar terhadap pengguna meliputi komunikasi interaktif, rujukan informasi kebahasaan, sumber stimulan, pedoman suatu kegiatan di kelas, dan dapat membantu bagi pendidik yang kurang berpengalaman untuk menumbuhkan kepercayaan diri Cunningsworth, (1995). Bahan ajar dalam penelitian ini termasuk dalam bentuk bahan ajar cetak.

Bahan ajar cetak dikatakan baik jika sesuai dengan empat kriteria. Empat kriteria tersebut menurut Doyin \& Syarifah (2008) meliputi pertama cakupan materi atau isi sesuai dengan kurikulum. Kedua, kebahasaan dan keterbacaan baik maksudnya bahwa bahasa yang digunakan dalam penulisan pada bahan ajar disesuaikan dengan tingkat psikologi dan tingkatan berpikir pengguna bahan ajar. Bahan ajar juga perlu memperhatikan keefektifan dalam penggunaan bahasa, sehingga bahan ajar yang dihasilkan mudah dipahami dan dibaca oleh peserta didik. Ketiga, sajian materi memenuhi prinsip belajar. Penyajian berpedoman pada prinsip belajar salah satunya yakni pembelajaran berpusat pada pengguna dan menarik. Keempat, kegrafikaan buku menarik, maksudnya perlu memperhatikan aspek kertas, warna, bentuk tulisan, dan ilustrasi yang mendukung materi pembelajaran.

Keterampilan berbahasa ada empat aspek yaitu keterampilan menyimak, berbicara, membaca, dan menulis. Menyimak dan membaca merupakan aspek reseptif, sementara berbicara dan menulis merupakan aspek produktif. Pada aktivitas berbicara, pengirim pesan mengirimkan pesan dengan menggunakan bahasa lisan. Sementara, dalam menyimak penerima pesan berupaya memberi makna terhadap bahasa lisan yang disampaikan penyampainya. Ketika kegiatan menulis, pengirim pesan mengirimkan pesan dengan menggunakan bahasa tulis. Di pihak lain, dalam membaca penerima pesan berupaya memberi makna terhadap bahasa tulis yang disampaikan penulisnya. Ketika mengirimkan pesan, pengirim harus memiliki keterampilan dalam melakukan proses encoding. Sebaliknya penerima pesan harus memiliki keterampilan proses decoding.

Menurut NYC (2009) Project Based Learning (PBL) adalah model pembelajaran dengan strategi pembelajaran mahasiswa harus membangun pengetahuan konten mereka sendiri dan mendemonstrasikan pemahaman baru melalui berbagai bentuk representasi. Tujuan utama model pembelajaran berbasis PBL ialah kemandirian mahasiswa dalam belajar untuk menyelesaikan tugas yang berupa proyek yang dihadapinya. Sehingga langkah awal dalam mengumpulkan serta mengintegrasikan pengetahuan baru berdasarkan pengalamannya dalam beraktifitas nyata. Karakteristik PBL yang pertama proyek merupakan ciri khas utama, kedua fokus pada pertanyaan atau masalah yang mendorong mahasiswa dalam mempelajari konsep-konsep, ketiga proyek melibatkan mahasiswa dalam penyelidikan konstruktivisme, keempat berpusat pada mahasiswa, dan kelima proyek realistis.

Keunggulan pembelajaran dengan menggunakan model PBL menurut Moursund dalam Wena (2013) terdapat delapan keunggulan, sebagai berikut. Pertama, meningkatkan motivasi mahasiswa untuk belajar dan mendorong mereka mengerjakan proyek. Dampaknya mahasiswa menjadi tekun belajar dan berusaha keras dalam menyelesaikan proyek. Kedua, peningkatan kemampuan dalam memecahkan masalah. Mahasiswa mempunyai pilihan untuk menyelidiki topik-topik yang berkaitan dengan masalah dunia nyata, saling bertukar pendapat antara kelompok yang membahas topik yang berbeda, mempresentasikan proyek atau hasil diskusi mereka. Ketiga, mahasiswa dalam kelompok lebih mengembangkan 
dan mempraktikkan keterampilan berbicara. Keempat, meningkatnya kemampuan mencari sumber yang berkualitas baik melalui kepustakaan maupun jurnal penelitian. Kelima, Memberikan pengalaman kepada mahasiswa dalam mengorganisasi proyek, mengalokasikan waktu, dan mengelola sumber daya seperti alat dan bahan menyelesaikan tugas. Keenam, memberikan kesempatan belajar bagi siswa untuk berkembang sesuai kondisi dunia nyata. Ketujuh, Meningkatkan kemampuan berpikir. Delapan, Membuat suasana belajar menjadi menyenangkan.

Inquiry merupakan suatu cara mengajar peserta didik, cara belajar dengan menggunakan keterampilan, proses, sikap, dan pengetahuan berpikir rasional Bruce \& Bruce (1992). Pada pendekatan inquiry penemuan merupakan bagian inti dari kegiatan pembelajaran. Pengetahuan dan keterampilan diperoleh dari menemukan sendiri. Tahapan dalam kegiatan pembelajaran meliputi merumuskan masalah, mengamati atau observasi, menganalisis, menyajikan, dan mengomunikasikan atau menyajikan hasil karya. Pembelajaran dengan menggunakan pendekatan inquiry penekanannya pada aspek pengembangan intelektual pengguna. Perkembangan intelektual menurut Piaget dalam Sanjaya (2010) dipengaruhi oleh empat faktor yang meliputi maturation atau kematangan, physical experience atau tindakan fisik yang dilakukan individu terhadap bendabenda yang ada di lingkungan sekitar, social experience atau aktivitas terhadap orang lain, dan equilibration atau proses penyesuaian antara pengetahuan yang dimiliki dengan pengetahuan yang telah ada. Dengan empat faktor yang memengaruhi tersebut, maka pendekatan inquiry mempunyai karakteristik pembelajaran dengan menggunakan pendekatan inquiry menurut pakar Hinrichsen \& Jarret dalam Zulfiani (2009) sebagai berikut. Pertama, koneksi yang menghubungkan pengetahuan dengan konsep komunitas atau kelompok. Kedua, desain dalam mengolah informasi atau pengetahuan oleh pengguna. Ketiga, investigasi berkelompok sehingga menemukan konsep yang tepat. Keempat, membangun pengetahuan melalui kegiatan praktik.

Keunggulan pendekatan inquiry dalam pembelajaran menurut pendapat Roestiyah (2001) terdapat sepuluh keunggulan, dengan penjelasan sebagai berikut. Pertama, membentuk dan mengembangkan konsep yang dapat dipahami. Kedua, membantu menemukan konsep yang mudah diingat. Ketiga, mendorong untuk berfikir dan bekerja atas inisiatif sendiri. Keempat, mendorong untuk berpikir intuitif. Kelima, memberi kepuasan yang bersifat instrik. Keenam situasi proses pembelajaran menjadi lebih menarik. Ketujuh, mengembangkan bakat dan melatih bersikap objektif, jujur, serta terbuka. Kedelapan, memberi kebebasan untuk belajar mandiri. Kesembilan, pembelajaran menjadi lebih bervariasi dan kreatif. Kesepuluh, memberikan waktu yang cukup sehingga dapat mengasimilasi dan mengakomodasi informasi.

Data lapangan menyatakan pendidik enggan dalam membuat sumber belajar inovatif. Sumber belajar yang digunakan mengandalkan slide power point. Mahasiswa dalam menyelesaikan tugas lebih sering asal copy paste dari internet. Ketika presentasi, mahasiswa hanya mengandalkan teman yang menguasai materi dalam menjawab pertanyaan peserta. Peserta yang menyimak juga lebih suka menyibukkan diri dengan bercanda, bermain HP, dan mengantuk. Ketika dibuka sesi pertanyaan, sebagian besar mahasiswa cenderung diam. Saat ujian mahasiswa cenderung menghafal materi tanpa memahami terlebih dahulu.

Dengan demikian, permasalahan yang difokuskan dalam penelitian ini meliputi pengembangan bahan ajar keterampilan berbahasa Indonesia, model PBL, dan pendekatan Inquiry. Karena ketiga hal tersebut sangat diperlukan sebagai bekal setelah mahasiswa lulus. Sehingga mahasiswa tidak hanya mahir dalam teori saja tetapi juga mahir dalam keterampilan berbahasa Indonesia. Alasan lain pentingnya pengembangan bahan ajar meliputi sepuluh hal. Sepuluh hal ini berdasarkan pendapat pakar Dick \& Carey (1996) yang meliputi motivasi belajar 
yang diinginkan, kesesuaian materi yang diberikan, mengikuti urutan yang benar, memuat informasi yang dibutuhkan, memuat latihan praktik, memberikan umpan balik, evaluasi yang sesuai dengan materi yang diberikan, menyediakan petunjuk untuk tindak lanjut, menyediakan petunjuk bagi peserta didik pada setiap tahapan yang dilakuakan, dan mudah diingat dan dipahami.

\section{METODE}

Metode yang digunakan pada penelitian berupa $R \& D$. Desain eksperimen yang digunakan adalah desain uji skala terbatas dan skala luas. Subjek yang diteliti adalah mahasiswa PGSD Universitas Muhammadiyah Purworejo. Lokasi penelitian di Kampus Plaosan Universitas Muhammadiyah Purworejo. Penelitian dilakukan pada kelas eksperimen, kelas kontrol, dan uji skala terbatas. Populasi pada penelitian ini berjumlah 130 mahasiswa. Pada kelas eksperimen diterapkan model pembelajaran PBL dan kelas kontrol tidak menggunakan model pembelajaran. Penggunaan uji statistik pada penelitian ini menggunakan uji statistik nonparametris sehingga tidak mensyaratkan data berdistribusi normal dan bersifat homogen. Uji yang dipakai pada penelitian ini adalah uji varian satu jalur.

Tahapan pembuatan bahan ajar keterampilan berbahasa Indonesia sebagai berikut. Pertama, potensi dan masalah dilakukan melalui survei prapenelitian melalui observasi bahan ajar serta kebutuhan bahan ajar. Analisis kebutuhan diperoleh dari lembar observasi prapenelitian dan pedoman wawancara untuk menganalisis bahan ajar. Lembar data kebutuhan diisi oleh subjek analisis kebutuhan yaitu peserta didik dan guru. Kedua, analisis kebutuhan terhadap bahan ajar. Ketiga, penyusunan desain bahan ajar keterampilan berbahasa Indonesia. Kegiatan yang dilakukan meliputi merancang dan menyusun buku keterampilan berbahasa Indonesia. Keempat, uji coba skala terbatas. Kelima revisi dan perbaikan produk. Keenam uji coba skala luas.

\section{HASIL DAN PEMBAHASAN}

Pengujian hipotesis pada penelitian ini menggunakan uji varian satu jalur. Alasan menggunakan uji varian satu jalur tipe ini yaitu karena pada penelitian ini peneliti menggunakan data pretest dan posttes. Berikut penjelasan tabel hasil uji homogenitas.

Tabel 1. Hasil Uji Homogenitas

Test of Homogeneity of Variances

\begin{tabular}{|r|c|c|c|}
\hline \multicolumn{4}{|l|}{ Hasil Uji Coba } \\
\hline Levene Statistic & $\mathrm{df} 1$ & $\mathrm{df} 2$ & Sig. \\
\hline 1.391 & 5 & 114 & .233 \\
\hline
\end{tabular}

Hasil uji homogenitas diketahui dari Levene Statistic sedangkan data yang dilihat dari tiga kolom, yakni df1, df2, dan sig. Hasil dari tiga data tersebut yakni (1) df1 yang berasal dari jumlah kelompok data pertama dengan hasil $5,(2)$ df2 berasal dari jumlah data - jumlah kelompok data dengan hasil 114, (3) Sig. atau signifikansi dengan hasil 0,233 . Karena nilai signifikansi pada Tabel uji homogenitas $>0,05$ maka, data hasil pretest dan posttest di kelas uji coba skala luas mempunyai varian yang sama atau homogen. Uji homogenitas di kelas terbatas dari hasil pretest dan posttest diketahui hasil signifikansi 0,065 dengan hasil df2 38. Jadi dalam uji skala terbatas variannya juga sama atau homogen.

Struktur isi Bahan Ajar Keterampilan Berbahasa Indonesia Berbasis Project Based Learning Dengan Pendekatan Inquiry terdiri dari empat kegiatan pembelajaran dan setiap kegiatan pembelajaran terdiri dari uraian materi, tujuan pembelajaran, proyek pembelajaran, pelaksanaan praktikum, serta penilaian praktikum. Kegiatan pertama, keterampilan berbicara dengan model pembelajaran PBL yang ditampilkan dalam kegiatan ini meliputi mahasiswa diminta mempraktikkan simulasi rapat, simulasi kegiatan wawancara, simulasi presentasi 
PKM, dan simulasi debat. Evaluasi dari kegiatan pertama mendongeng sebuah cerita atau legenda untuk jenjang sekolah dasar. Penilaian pada kegiatan pertama keterampilan berbicara terdiri dari tiga aspek sebagai berikut. Pertama aspek kebahasaan unsur yang dinilai meliputi kosa kata, tata bahasa, lafal atau ucapan, intonasi, tempo, tekanan, dan jeda, kedua aspek gagasan yang meliputi unsur kesesuaian topik, kelengkapan, dan keruntutan. Ketiga aspek nonkebahasaan yang meliputi unsur volume, kelancaran, pandangan, ekspresi wajah, bahasa tubuh, dan durasi.

Kegiatan kedua, keterampilan membaca dengan model pembelajaran PBL yang ditampilkan dalam kegiatan ini setiap kelompok diberi tantangan untuk membaca secepat mungkin dari naskah yang disediakan oleh dosen. Tujuannya mengasah keterampilan membaca mahasiswa dengan teknik scanning dan skimming. Penilaian pada kegiatan kedua untuk teknik membaca skimming dari kecepatan waktu sedangkan teknik membaca scanning waktu yang dibutuhkan untuk membaca, dan jumlah kata pada teks bacaan tersebut. Kegiatan ketiga, keterampilan menyimak dengan model pembelajaran PBL yang ditampilkan dalam kegiatan ini setiap kelompok diberi tantangan untuk menuliskan naskah cerita dari video dongeng, berita, dan acara diskusi ilmiah yang ditayangkan. Penilaian pada kegiatan ketiga keterampilan menyimak meliputi ejaan, tanda baca, penggunaan huruf kapital, keruntutan isi, dan kelengkapan paragraf. Kegiatan keempat, keterampilan menulis dengan model pembelajaran PBL yang ditampilkan dalam kegiatan ini menulis karya ilmiah berupa PKM. Penilaian pada kegiatan keempat keterampilan menulis meliputi kreativitas yang terdiri dari gagasan dan keunggulan produk atau jasa, peluang pasar, potensi perolehan profit dan keberlanjutan usaha, penjadwalan kegiatan dan personalia.

Pembagian kelompok dilakukan secara acak agar mahasiswa mampu berkomunikasi dengan baik dan berkompetisi dengan sehat antar angota kelompok dan antar kelompok. Begitu juga peran dosen yang bertindak sebagai fasilitator juga sangat penting untuk memperlancar jalannya pembelajaran. Dalam penelitian ini, penerapan model PBL dengan pendekatan inquiry adalah sebagai berikut: pertama dosen merefleksi materi dengan membawa persepsi mahasiswa ke masalah, kedua dosen memberikan beberapa rumusan masalah kepada mahasiswa, ketiga dosen menjelaskan aturan dalam mengerjakan proyek, keempat mahasiswa bersama dengan kelompoknya mengamati dan berdiskusi, kelima mahasiswa menganalisis dan menyajikan hasil, dan keenam mengomunikasikan atau mempresentasikan hasil proyek dari kelompoknya.

Langkah-langkah dalam kegiatan pembelajaran dengan pendekatan inquiry dan model PBL menurut Munandar, (2009) sebagai berikut. Pertama, perencanaan, pada tahapan ini kegiatan yang dilakukan adalah merancang seluruh proyek, kegiatan dalam langkah ini adalah mempersiapkan proyek, secara lebih rinci meliputi pemberian informasi tujuan pembelajaran, guru menyampaikan fenomena nyata sebagai sumber masalah, pemotivasian dalam memunculkan masalah dan pembuatan proposal. Selanjutnya mengorganisir pekerjaan kegiatannya meliputi merencanakan proyek, secara lebih rinci mencakup: mengorganisir kerjasama, memilih topik, memilih informasi terkait proyek, membuat prediksi, dan membuat desain investigasi. Kedua kreativitas, dalam tahapan ini mahasiswa mengembangkan gagasan-gagasan proyek, mengkombinasikan ide yang muncul dalam kelompok, dan membangun proyek. Tahapan kedua ini termasuk aktivitas pengembangan dan dokumentasi. Pada tahapan ini pula siswa menghasilkan suatu produk yang nantinya akan dipresentasikan dalam kelas. Ketiga, memproses yang meliputi presentasi proyek dan evaluasi. Pada presentasi proyek akan terjadi komunikasi secara aktual kreasi ataupun temuan dari investigasi kelompok, sedangkan pada tahapan evaluasi akan dilakukan refleksi terhadap hasil proyek, analisis dan evaluasi dari proses-proses belajar. 
Berdasarkan analisa keterampilan berbahasa Indonesia mahasiswa PGSD antara kelas eksperimen dan kelas ada perbedaan dimana kelas eksperimen lebih baik. Hal ini tercermin dari pengamatan penilaian sikap diketahui bahwa mahasiswa mulai mengalami perubahan sikap dari pasif menjadi aktif. Sikap selama perkuliahan sudah tercermin dengan adanya respon baik melalui pertanyaan, menanggapi, memberikan pendapat atau saran. Dengan demikian dapat dikatakan bahwa pengembangan bahan ajar berbasis project based learning dengan pendekatan inquiry pada mata kuliah keterampilan berbahasa Indonesia dapat meningkatkan rasa percaya diri dan motivasi mahasiswa dalam berinteraksi di perkuliahan.

\section{SIMPULAN}

Berdasarkan analisis data yang diuraikan sebelumnya maka dapat disimpulkan hasil uji normalitas dalam uji coba skala terbatas yang pertama diketahui bahwa nilai sig. pretest dan posttest uji coba pertama dalam kolom Kolmogorov-Smirnov diperoleh 0,200 dan 0,035. Nilai sig. pretest dan posttest uji coba kedua dalam kolom Kolmogorov-Smirnov diperoleh 0,028 dan 0,200. Dengan demikian, nilai signifikansi dalam kolom Kolmogorov-Smirnov untuk seluruh variabel uji coba skala terbatas lebih besar dari 0,05 dan disimpulkan bahwa pretest dan posttest berdistribusi normal. Hasil uji normalitas dalam uji coba skala luas di Semarang yang pertama diketahui bahwa nilai sig. pretest dan posttest uji coba pertama dalam kolom Kolmogorov-Smirnov diperoleh 0,200 dan 0,200. Nilai sig. pretest dan posttest uji coba kedua dalam kolom Kolmogorov-Smirnov diperoleh 0,200 dan 0,058 . Dengan demikian, nilai signifikansi dalam kolom KolmogorovSmirnov untuk seluruh variabel uji coba skala luas lebih besar dari 0,05 dan disimpulkan bahwa pretest dan posttest berdistribusi normal.

Berdasarkan kesimpulan dari penelitian ini, maka kepada para dosen, peneliti mengemukakan beberapa saran sebagai berikut. Pertama, hendaknya dosen menerapkan model pembelajaran PBL supaya dapat memperbaiki kualitas perkuliahan. Kedua, dalam kegiatan perkuliahan, hendaknya dosen menerapkan pendekatan pembelajaran yang mengaktifkan mahasiswa.

\section{DAFTAR PUSTAKA}

Bruce, W.C. \& J.K. Bruce. 1992. Teaching with Inquiry. Maryland: Alpha Publishing Company, Inc.

Cunningsworth, A. 1995. Choosing your Course-Book. Oxford: Heilnemann.

Dick, W., \& Carey, L. 1996. The Systematic Design of Instruction. New York: Longman. Diperoleh dari www.hastudio.us/thesystematicdesigno finstruction.pdf (diunduh pada tanggal 06 September 2014)

Doyin, M., \& Syarifah, E. 2008. Karya Tulis IImiah: BentukdanTeknikPenulisannya. Semarang: Bandungan Institut.

Munandar. 2009. Pengembangan Kreativitas Anak Berbakat. Jakarta: Rineka Clpta.

NYC Departement of Education. 2009. Project Based Learning: Inspiring Middle School Student to Engage in Deep and Active Learning. New York: Division of Teaching and Learning Office.

Roestiyah, N., K. 2001. Strategi Belajar Mengajar. Jakarta: Rineka cipta.

Sanjaya, W. 2010. Strategi Pembelajaran Berorientasi Standar Proses Pendidikan. Jakarta: Kencana. 
Sujarwo. 2008. Penyusunan Bahan Ajar Tematik. Yogyakarta: Universitas Negeri Yogyakarta.

Tomlinson, B. 2012. State-of-the-Art Article Materials Development for Language Learning and Teaching. Cambridge: CUP. Diperoleh dari www.cambridge.org/download_file/74 0388/0/ (diunduh pada tanggal 17 Januari 2017)

Wena, M. 2013. Strategi pembelajaran inovatif kontemporer: suatu tinjauan konseptual operasional. Jakarta: Bumi Aksara.

Zulfiani. 2009. Strategi Pembelajaran Sains. Jakarta: Lembaga penelitian UIN Jakarta. 